\title{
Likely Utopic Technological Future
}

\author{
Jorge Luis Cuyubamba Domínguez
}

Peru

The science is not only necessary in this century, but it has also been of paramount importance during the whole history of mankind since the ancient civilizations started, although it may have not been regarded as science itself, the simple use of knowledge to bring benefits to a whole society is essential (Chai et al., 2019). Frankly speaking, we need science right now more than even because the singularity and threats of our own evolution and development is growing exponentially, so we should redirect the use of science for the welfare of mankind.

Technology certainly can bring peace to the whole globe. The same way as any other fields of human knowledge. To be more specific, I can give some examples, the use of algorithms in the legal system in one of them, the facial recognition through artificial intelligence, which means much more effective surveillance for a big population especially in the giants modern cities where the threatens are everywhere (although it may sound non ethical, or very controversial to always possess very high control over everyone), or even technology in the use of global commerce, it can make the citizens increase their day to day trade, which will generate more income, hence poverty and violence will diminish severely. Therefore, yes, technology can indeed bring peace to the world (Axworthy, \& Dorn, 2016).

Furthermore, there is a field, I would like to emphasize, and it is the outer space. In this century, in my opinion, we are witnessing a big revolution in this industry, as we all know NASA already shut down their own spaceships programs, and is going to delegate all its missions to private corporations, while, on the other hand, China is taking an enormous role in the outer space by launching their own space station, yes their own, China is so powerful now that is basically taking control of the outer space at a high speed (Elliott et al., 2015).

We should all care of this because besides the world security (nuclear satellites and other high advanced weapons are better controlled from outer space), there is a topic that very few people know which is the outer space mining. The moon and some other satellites to give some small examples, have more natural (minerals and others) resources than many nations from earth together, so it means that if a country such as China or a giant private USA corporation start getting these resources and make them profitable, it means that many countries (developing ones) which economy are based on minerals or natural resources may totally go bankrupts, destabilizing even the world's economy. It sounds like science fiction, 
JOURNAL OF LATIN AMERICAN SCIENCES AND CULTURE

Vol. 2 - 2020

Universidad Privada del Valle - Bolivia

https://doi.org/10.52428/2788891.v2i2.47

but it is very likely to occur within a decade, that is why Luxemburg has started to regulate this industry by even creating legal laws that should firmly apply over any entity that wants to explore or use the resources from the outer space.

Finally, I think that there are many potential big threats coming in the next decade, but I am absolutely convinced that the good-hearted humans overpass the selfishness of the other ones, so we will use all the power of knowledge (in science and technology) to make a better world, and yes, I include myself as one of the "good ones".

\section{REFERENCES}

Axworthy, L., \& Dorn, A. W. (2016). New Technology for Peace \& Protection: Expanding the R2P Toolbox. Daedalus, 145(4), 88-100.

Chai, C. S., Hwee Ling Koh, J., \& Teo, Y. H. (2019). Enhancing and modeling teachers' design beliefs and efficacy of technological pedagogical content knowledge for $21 \mathrm{st}$ century quality learning. Journal of Educational Computing Research, 57(2), 360384.

Elliott, R. J., Strobl, E., \& Sun, P. (2015). The local impact of typhoons on economic activity in China: A view from outer space. Journal of Urban Economics, 88, 50-66.

Fuentes de financiamiento: Esta investigación fue financiada con fondos del autor.

Declaración de conflicto de intereses: El autor declara que no tiene ningún conflicto de interés.

Copyright (c) 2021 Jorge Luis Cuyubamba Domínguez

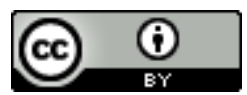

Este texto está protegido por una licencia Creative Commons 4.0 .

Usted es libre para Compartir — copiar y redistribuir el material en cualquier medio o formato- $\mathrm{y}$ Adaptar el documento —remezclar, transformar y crear a partir del material - para cualquier propósito, incluso para fines comerciales, siempre que cumpla la condición de:

Atribución: Usted debe dar crédito a la obra original de manera adecuada, proporcionar un enlace a la licencia, e indicar si se han realizado cambios. Puede hacerlo en cualquier forma razonable, pero no de forma tal que sugiera que tiene el apoyo del licenciante o lo recibe por el uso que hace de la obra. 